\title{
Study of the influence of barley varieties with different resistance to barley net blotch on the change in the structure of the hemibiotrophic pathogen population by morphological and cultural characteristics and virulence
}

\author{
Galina Volkova $^{1, *}$, Yana Yakhnik $^{1}$, Alena Smirnova $^{2}$, and Egor Klychnikov ${ }^{3}$ \\ ${ }^{1}$ All-Russian Research Institute of Biological Plant Protection, Krasnodar-39, 350039, Russia \\ ${ }^{2}$ High comprehensive school №96, Krasnodar, Korenovskaya St., 35, 350005, Russia \\ ${ }^{3}$ Gymnasium №87, Krasnodar, 9 Boulevard Ring Street, 350089, Russia
}

\begin{abstract}
The study is devoted to the analysis of the correlation of morphological and cultural characteristics and virulence of Pyrenophora teres Drechs. isolates, and various resistance to the pathogen of barley varieties (Versal, Kubagro-1, Romance). The main morphological types of colonies of the fungus isolates obtained from the barley varieties with different resistance were determined. It was found that the higher degree of resistance of the variety, the faster growth rate of colonies, the intensity of sporulation and heterogeneity of the population on the basis of virulence increase. The most common races were detected in the populations of $P$. teres isolated from different varieties of barley. We found that the selection for the virulence of the pathogen population in Versal variety with a high level of non-specific resistance was carried out with a wider spectrum of diversity.
\end{abstract}

\section{Introduction}

The cultivation of cereals on an industrial scale involves complex protection against diseases caused by phytopathogens. Hemibiotrophic parasites are under the special control due to the widespread increase in their harmfulness in recent decades. The main barley (Hordeum vulgare L.) disease worldwide is net blotch caused by ascomycete Pyrenophora teres Drechs. [1]. The expansion of the range of $P$. teres specialization in parasitization on wheat (Triticum aestivum L.) [2,3] is of a particular concern. Barley is one of the most important crops of the agro-industrial complex, occupying the fourth place among the most cultivated cereal crops and one of the main types of grain products sold by Russia. In the Southern Federal District of the Russian Federation, barley net blotch is the most harmful and dangerous disease [4].

\footnotetext{
* Corresponding author: galvol.bpp@yandex.ru
} 
Global crop production is focused on the conservation of resources and the production of ecologically safe products, which makes the breeding of genetically protected varieties really important. Due to the fact that the annual loss of winter barley from the pathogen is from 20 to $40 \%$, a complex crop protection plan is necessary, which is especially true for susceptible varieties $[5,6]$. There are no highly resistant varieties to barley net blotch pathogen [7]. The resistance of the host plant is consistent with the gene-by-gene model, but the significant variability of the pathogen genotype and the presence of two forms that differ in genotype (Pyrenophora teres $f$. teres — net form (net type) and Pyrenophora teres f. Maculate - spot-form (round-spotted type)) causes difficulties in breeding and variety selection in production crops $[8,9]$.

For intensive plant breeding and an immunological assessment of the resistance of various barley varieties, it is necessary to develop a large amount of inoculum. The study of the morphological and cultural characteristics of the pathogen is important for the development of various types of synthetic pathogen populations in the preparation of a scientifically based breeding program for the cultivation of disease resistant barley varieties [10].

Determining the population structure of the barley net blotch pathogen is of great practical importance for the breeding of disease-resistant varieties, increasing the efficiency of plant protection measures and improving the ecological component of crops $[8,11,12]$. The genetic polymorphism of the pathogen population is determined by the heterogeneity of the host plant. This factor suggests the formation of a micromycete population with various morphological and cultural characteristics, determined by differences in the genetic structure due to the propagation of clones and genetically close lines in varieties that are different in disease resistance [13, 14]. Genetic diversity is an important element in the study of population structure. It is worth noting the narrow-local isolation of $P$. teres due to the low mobility of conidia, which are the main method of pathogen distribution during the growing season [12]. At the same time, many researchers, when analyzing the population structure on an international set of differentiating varieties, note a high genetic variability of the population based on virulence [11, 15-17].

The aim of this research was to study the morphological and cultural characteristics and virulence of the isolates of barley net blotch pathogen, isolated from the barley varieties, differing in resistance to the pathogen.

\section{Materials and methods}

Analysis of morphological and cultural characteristics was carried out according to three criteria: colony growth rate, appearance, fungal sporulation intensity. For this analysis, monoconidial isolates were isolated from one affected leaf by transferring one conidia to a pure carrot-beetroot agar culture. Infectious material was collected in 2020 under the conditions of a natural infectious background of the ARRIBPP field from the varieties differing in resistance to the barley net blotch pathogen in the Z32 phase according to Zadoks. Varieties with different levels of nonspecific resistance were selected for the research: moderately resistant to $P$. teres (MR) Versal variety, moderately susceptible (MS) Kubagro-1 variety, and the highly susceptible (HS) Romance variety. To study the population structure, $30 \mathrm{P}$. teres monoconidial isolates were obtained from each of the three varieties. To study the growth rate, colony morphotypes, and pathogen sporulation rate, we selected 10 isolates from each barley variety. To study the growth rate of colonies, monoconidial isolates were incubated for 7 days, then $10 \mathrm{~mm}$ diameter mycelial discs were transferred to clean nutrient media from each isolate with tree replications. Cups with mycelial discs were incubated in the dark for 10 days at a temperature of $+23^{\circ} \mathrm{C}$. on the $3^{\text {rd }}$, $6^{\text {th }}, 10^{\text {th }}$ days, the diameter of the mycelium was measured, and based on these data, the average colony growth rate was calculated. Colony morphology was determined on the $10^{\text {th }}$ 
day with the proposed scheme according to the existing method [10]. Morphological types of colonies are divided into groups according to the morphological characteristics of the mycelium and have the corresponding letter designation (Fig.1).

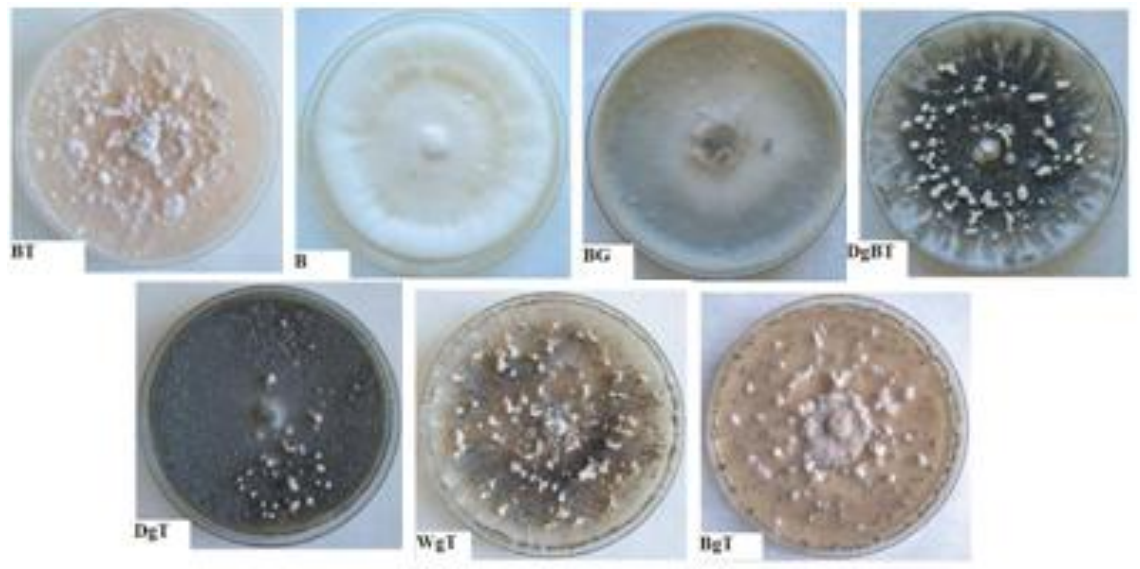

Fig. 1. Characteristics of morphological types of colonies $P$. teres Source: https://pdfs.semanticscholar.org/9b63/29cd2d67a2dala2a09a1de3b498c779dab59.pdf

The sporulation intensity was studied by transferring monoconidial isolates from different varieties into Petri dishes with nutrient medium and following incubation under ultraviolet lamps for 14 days. $10 \mathrm{ml}$ of conidial suspension were prepared from each Petri dish, then the number of spores in $1 \mathrm{ml}$ of the suspension was counted using a Goryaev chamber. Colonies were ranked for weakly sporulating $-2 \times 103$ conidia/ml; medium sporulating $-5 \times 103$ conidia/ml; highly sporulating $-7 \times 103$ conidia $\mathrm{ml}$.

The study of the diversity of the population structure based on virulence was carried out using a standard set of differentiating varieties [16]. To study the resistance of barley variety samples to $P$. teres, the plants were hydroponically grown to the seedling stage (two leaf phase), then inoculated with the known conidia titer, and the wet period was maintained using polyethylene insulators for 15-20 hours. For the preparation of $P$. teres inoculum, a freshly isolated spore-containing culture was used, from which mycelium was scraped off and an aqueous suspension was prepared. Assessment of the intensity of damage to barley leaves by net blotch was carried out according to the standard Babayants scale. The type of reaction of the differentiator variety seedling from 0 to 15 points referred to the resistant type, from 16 to 100 points to the susceptible type of reaction.

To identify the differences between the samples, the criterion of the smallest significant difference ( $d \geq$ HCP 05) was used; for the statistical analysis of the characteristics correlation, the linear Pearson correlation coefficient (r) was used. The calculation was performed using the Statistica 13.3 program.

\section{Results and discussion}

We revealed significant differences in the growth rate of isolate colonies collected from the barley varieties differing in resistance to the pathogen (Table 1).

The growth rate of isolates colonies ranged from 6.3 to $10.6 \mathrm{~mm}$ per day. The average growth rate of the colonies isolated from a moderately resistant Versal variety was the highest and amounted up to $9.0 \mathrm{~mm} /$ day. P. teres colonies isolated from the moderately susceptible Kubagro -1 variety grew more slowly, at a rate of $8.6 \mathrm{~mm} /$ day. Even slower was 
the growth rate of the pathogen colonies collected from the highly susceptible Romance variety, which average value was $7.6 \mathrm{~mm}$ /day. Significant differences were found between the growth rate of the isolates colonies collected from the varieties differing in the resistance to the pathogen.

Table 1. The growth rate of the $P$. Teres monoconidial isolates colonies, collected from the barley varieties differing in resistance, $\mathrm{mm} / \mathrm{ay}$

\begin{tabular}{|l|c|c|c|c|c|c|c|c|c|c|c|}
\hline \multirow{2}{*}{ Variety } & Resistance & \multicolumn{8}{|c|}{ The growth rate of the pathogen isolates colonies } \\
\cline { 3 - 13 } & characteristics & 1 & 2 & 3 & 4 & 5 & 6 & 7 & 8 & 9 & 10 \\
\hline Versal & MR & 8.8 & 9.3 & 8.9 & 9.0 & 9.0 & 8.3 & 9.0 & 8.5 & 10.6 & 8.7 \\
\hline Kubagro-1 & MS & 7.3 & 9.2 & 7.5 & 8.1 & 8.7 & 9.2 & 8.7 & 9.1 & 9.1 & 8.8 \\
\hline Romance & HS & 9.0 & 8.3 & 6.3 & 7.5 & 6.3 & 8.7 & 7.3 & 6.6 & 7.6 & 8.4 \\
\hline \multicolumn{10}{|c|}{0.73} \\
\hline
\end{tabular}

In the course of the research we identified 7 morphological types of $P$. teres colonies (Table 2).

Table 2. Morphotypes frequency of $P$. teres colonies collected from the barley varieties differing in resistance

\begin{tabular}{|l|c|c|c|c|c|c|c|c|}
\hline \multirow{2}{*}{ Variety } & \multirow{2}{*}{$\begin{array}{c}\text { Resistance } \\
\text { characteristics }\end{array}$} & \multicolumn{8}{|c|}{ Colony morphotype, pcs. } \\
\cline { 3 - 10 } & MR & 2 & 5 & 3 & 9 & 8 & 0 & 3 \\
\hline Versal & MS & 3 & 8 & 5 & 6 & 3 & 0 & 5 \\
\hline Kubagro-1 & HS & 3 & 8 & 3 & 4 & 5 & 2 & 5 \\
\hline Romance & 8 & 21 & 11 & 19 & 16 & 2 & 13 \\
\hline \multicolumn{7}{|l}{ Total } \\
\hline
\end{tabular}

Among the colonies of $P$. teres monoconidial isolates, isolated from the barley varieties differing in resistance, the DgT colony type prevailed, having dark grey mycelium with light bunches and a black substrate (23.3 \% frequency) (Fig.2). With a frequency of $21.1 \%$, there was a colony morphotype with light grey fluffy BG mycelium in the population. The lowest frequency was observed in colonies with morphotype B, which has a light, almost white mycelium with a pinkish or grey shade with light bunches. It was present only in colonies of the fungal isolates collected from the Romance variety, and amounted up to $2.2 \%$ of the total.

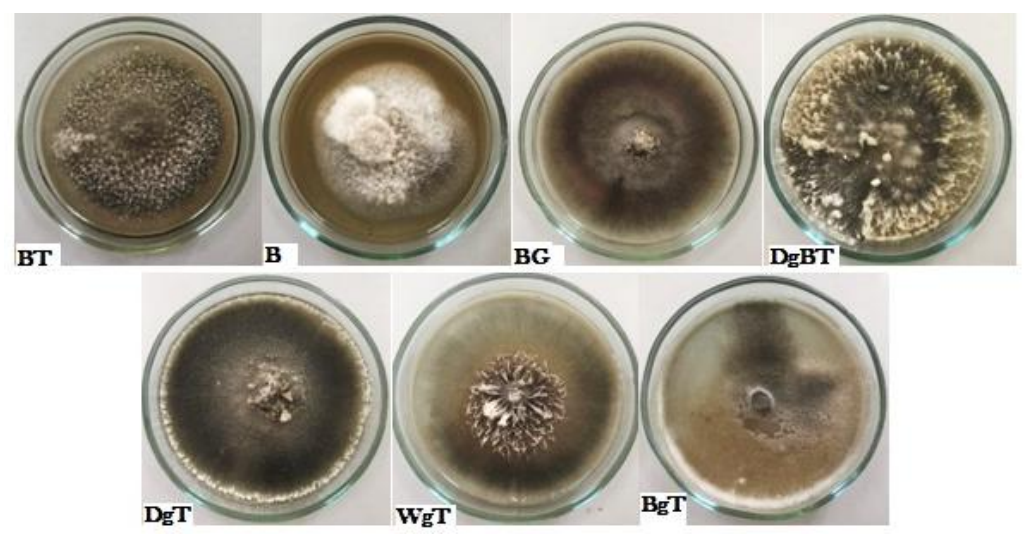

Fig. 2. P. teres isolates colonies isolated from the barley varieties differing in resistance with different morphological types (original)

Among the pathogen isolates collected from a moderately resistant Versal variety, isolates with light grey fluffy mycelium (BG) and white low mycelium with dark grey spots 
and light bunches (WgT) predominated. The moderately susceptible Kubagro-1 variety was dominated by isolates with dark grey with light bunches and a black substrate (DgT) and light grey mycelium (BG). Highly susceptible Romance variety included all colony morphotypes, but the DgT morphotype prevailed.

The highest sporulating ability was detected in isolates collected from the moderately resistant Versal variety, amounting up to $7 \times 103$ conidia/ml. Colonies with an index of 4.3 $\times 103$ conidia/ml, isolated from the moderately susceptible Kubagro- 1 variety, can be classified as mid-sporulating. Pathogen isolates from the highly susceptible Romance variety showed the lowest sporulation level, the average value was $1.3 \times 103$ conidia $/ \mathrm{ml}$.

A comparative analysis by the virulence of $P$. teres isolates collected from three barley varieties differing in resistance to the pathogen revealed some differences (Table 3).

Table 3. Characteristics of $P$. teres populations isolated from the barley varieties differing in resistance by the number of virulent isolates to differentiating varieties

\begin{tabular}{|l|c|c|c|c|c|c|c|c|c|c|}
\hline & & \multicolumn{7}{|c|}{ Percentage of virulent isolates on differentiating varieties } \\
\cline { 3 - 11 } Variety & $\begin{array}{c}\text { Resistance } \\
\text { character- } \\
\text { ristics }\end{array}$ & Skiff & Prior & $\begin{array}{c}\text { CI } \\
9825\end{array}$ & $\begin{array}{c}\text { Cana- } \\
\text { dian } \\
\text { Lake } \\
\text { Shore }\end{array}$ & c-8755 & CI 5791 & $\begin{array}{c}\text { Har } \\
\text { bin }\end{array}$ & c-20019 & $\begin{array}{c}\text { Har } \\
\text { ring } \\
\text { ton }\end{array}$ \\
\hline Versal & MR & 66 & 46 & 53 & 76 & 0 & 100 & 0 & 46 & 93 \\
\hline Kubagro-1 & MS & 100 & 23 & 6 & 43 & 3 & 100 & 0 & 30 & 100 \\
\hline Romance & HS & 26 & 13 & 30 & 70 & 0 & 90 & 0 & 16 & 100 \\
\hline
\end{tabular}

Significant differences in the number of virulent isolates to differentiating varieties Skiff, Prior, CI 9825 and c-20019 were revealed. It should be noted that there is a correlation between a decrease in the number of virulent isolates to differentiating varieties Prior and c-20019 and a decrease in the resistance degree of the host plant to the pathogen.

Figure 3 shows the indicators of the damage degree of barley plants, average virulence, and the number of the identified races in $P$. teres populations collected from the varieties differing in resistance (Fig.3).

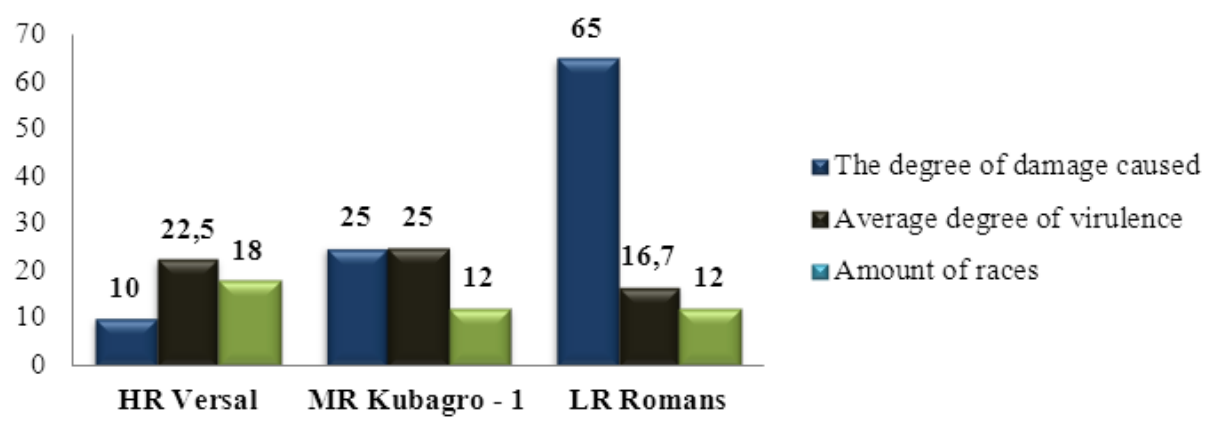

Fig. 3. Damage degree, average virulence, and the number of the identified races in $P$. teres populations collected from the barley varieties differing in resistance

In the pathogen population collected from the moderately resistant Versal variety with $10 \%$ plant damage, the number of identified races was 18 ; from Kubagro- 1 variety $-25 \%$ and 12 races; from the Romance variety $-65 \%$ and 13 races, respectively. The greater diversity of the racial composition of the $P$. teres population from the Versal variety indicates a high evolutionary adaptability of the pathogen in overcoming the resistance of the variety host plant. 
We found that the pathogen population isolated from the moderately susceptible Kubagro-1 variety $(25.0 \%)$ had the highest virulence and the fungus population from the highly susceptible Romance variety had the smallest virulence $(16.7 \%)$. The statistical analysis showed a linear negative correlation between the damage degree of the host plant and the average virulence of the pathogen $(\mathrm{r}=-0.59)$.

An analysis of the $P$. teres population structure by racial composition revealed high diversity. So, we identified 43 races among the studied 90 pathogen isolates (Table 4).

Table 4. Frequency of the most common races in P. Teres populations, collected from the barley varieties differing in resistance, $\%$

\begin{tabular}{|c|c|c|c|c|c|c|c|c|c|c|c|c|c|c|}
\hline \multirow{2}{*}{ Variety } & \multirow{2}{*}{$\begin{array}{c}\text { Resistance } \\
\text { characteristics }\end{array}$} & \multicolumn{13}{|c|}{ Race } \\
\hline & & 651 & 551 & 411 & 053 & 751 & 453 & 611 & 153 & 051 & 011 & 753 & 451 & 613 \\
\hline Versal & MR & 9 & 6 & 0 & 6 & 6 & 9 & 3 & 3 & 0 & 0 & 13 & 0 & 0 \\
\hline Kubagro-1 & MS & 6 & 3 & 20 & 0 & 0 & 9 & 6 & 0 & 0 & 0 & 0 & 20 & 9 \\
\hline Romance & HS & 6 & 9 & 3 & 6 & 3 & 0 & 0 & 3 & 26 & 20 & 0 & 0 & 0 \\
\hline
\end{tabular}

Races 651 and 551 were observed in pathogen populations collected from all analyzed barley varieties. Races 411, 053, 751, 453, 611, 153 were found on two barley varieties, Versal and Romance varieties had three of the above mentioned races, two of the races were found on Versal and Kubagro-1 varieties, and one of the races was found on Kubagro1 and Romance varieties. Thus, in the pathogen population from the moderately resistant Versal variety, among the identified 18 races there were 11 original and 7 identical; from the moderately susceptible Kubagro -1 variety among the 12 races there were 7 original and 5 identical; from the highly susceptible Romance variety among the 13 races, there were 7 original and 6 identical races.

The moderately resistant Versal variety was noted to favor the formation of a greater number of $P$. teres races. This indicates a high competitive ability of the pathogen population collected from a more resistant variety, which provokes stabilizing selection with the elimination of "extra" genes and an increase in the number of $P$. teres clones with optimal adaptive properties under these conditions, which is consistent with the studies of several authors $[5,6,16,18]$.

\section{Conclusions}

Based on the studies, it can be concluded that barley varieties resistant to $P$. teres induce the appearance of the most aggressive and rapidly propagating pathogen populations, since, in a comparative analysis, isolates from a moderately resistant variety showed the highest colony growth rates, the most intense sporulation, and the maximum of the identified number of races. The dominant races of $P$. teres have been determined. The selection of the pathogen virulence clones was carried out on the Versal variety, exhibitting a high level of non-specific resistance, with a wide range of diversity, including pathogen races identified from less resistant varieties. The obtained results are consistent with the previous studies proving that new aggressive and diverse genotypes accumulate in the $P$. teres population from resistant barley varieties, among which the unadaptable ones are eliminated by natural selection pressure, and the most adaptable ones intensively propagate in clones, significantly increasing the virulence of the population, which ultimately negatively affects plant protection in industrial crops.

The studies were carried out in the framework of the grant of the Russian Foundation of Basis Research and the Administration of Krasnodar Krai r_Mentor No. 19-416-235005. 


\section{References}

1. M.J. Muria-Gonzalez, K.G. Zulak, E. Allegaert, R.P. Oliver, S.R. Ellwood, $\begin{array}{lllll}\text { Physiological and Molecular Plant Pathology, } 109 & \text { (2020) }\end{array}$ https://www.sciencedirect.com/science/article/pii/S088557651930219X?via\%3

2. L.A. Mikhailova, I.G. Ternuk, V.P. Mironenko, Mycology and Phytopathology, 44 (2010) https://www.binran.ru/files/journals/MiF/2010 44/MiF 2010 44_1_Mikhailova etal.pdf

3. A.E. Perelló, L. Couretot, A. Curti, J.P. Uranga, V.F. Consolo, Crop Protection, 122 (2019). https://www.sciencedirect.com/science/article/abs/pii/S0261219419301036

4. A.A. Doncova. Scientific Journal of KubSAU, 113 (2015) https://cyberleninka.ru/article/n/ispolzovanie-molekulyarnyh-metodov-selektsii-naustoychivost-k-setchatoy-pyatnistosti-yachmenya-obzor

5. O.S. Afanasenko, A.V. Koziakov, P.E. Hedlay, N. Lashina, A.V. Anisimova, O. Manninen, J., Marja, E. Potokina, Genetics, 5 (2015) https://link.springer.com/article/10.1134/S2079059715030028

6. I.V. Rozanova, N.M. Lashina, Z.S. Mustafin, BMC Genomics, 20 (2019) https://bmcgenomics.biomedcentral.com/articles/10.1186/s12864-019-5623-3

7. J. Wesley, W. Deng, J.G.L. Mullins, S. West, P. Wang, N. Besharat, S.R. Ellwood, R. Oliver, F. Lopez-Ruiz, Frontiers in Microbiology, 7 (2016) https://www.frontiersin.org/articles/10.3389/fmicb.2016.01279/full

8. M.S. McLean, B.J. Howlett, G.J. Hollaway, Australasian Plant Pathology, 39 (2010)

9. S. Ellwood, Z. Liu, R. A. Syme, Z. Lai, J. K. Hane, F. Keiper, C.S. Moffat, R. P. Oliver, T. L. Friesen, Genome Biology, $11 \quad$ (2010) https://genomebiology.biomedcentral.com/articles/10.1186/gb-2010-11-11-r109

10. A. Baturo-Ciesniewska, A. Grabowski, A. Pańka, Dariusz, Plant Pathology, 94 (2012) https://pdfs.semanticscholar.org/9b63/29cd2d67a2da1a2a09a1de3b498c779dab59.pdf

11. A. Akhavan, S. Strelkov, H. Askarian, S. Kher, M. Fraser, R. Kutcher, K. Turkington, Canadian Journal of Plant Pathology, 38 (2016) https://www.tandfonline.com/doi/abs/10.1080/07060661.2016.1159617

12.M.M. Levitin, N.V. Mironenko, Biosphere 2 (2016) https://www.google.ru/url?sa=t\&rct=j\&q=\&esrc=s\&source=web\&cd=1\&ved=2ahUKEwi W9Mr0sITpAhUjyKYKHYW7AUgQFjAAegQIAhAB\&url=https $\% 3 \mathrm{~A} \% 2 \mathrm{~F} \% 2$ Frucont.ru \%2Ffile.ashx\%3Fguid\%3D2d646584-b190-46c2-82d50567128c2ea4\&usg=AOvVaw0PuLmNVAmMTpAWpi4acIi1

13. J. König, D. Perovic, D. Kopahnke et al., Mol Breeding, 32 (2013) https://link.springer.com/article/10.1007/s11032-013-9897-x?shared-article-renderer

14. Z. Kang, X. Li, A. Wan, M. Wang, X. Chen, Canadian Journal of Plant Pathology, 41:3 (2019) https://www.tandfonline.com/doi/abs/10.1080/07060661.2019.1577301

15. A.V. Anisimova, I.U. Novikova, F. Novakazi, D. Kopahnke, Mycology and Phytopathology, 51 (2017)

16. I.V. Rozanova, N.M. Lashina, Z.S. Mustafin, O.S. Afanasenko, BMC Genomics 20 (2019) https://link.springer.com/article/10.1186/s12864-019-5623-3

17. Z. H. Liu, S. Zhong, A. K. Stasko, M. C. Edwards, T. L. Friesen, Population Biology, 102 (2012) https://apsjournals.apsnet.org/doi/pdf/10.1094/PHYTO-09-11-0243

18. N. V. Mironenko, O.S. Afanasenko, Mikologiya i Fitopatologiya, 45 (2011) 